\title{
A comparison of the effects of Propofol and Thiopental on tear production in dogs ${ }^{1}$
}

\author{
Kelly Cristine de Sousa Pontes*2, Andrea Pacheco Batista Borges ${ }^{3}$, Renato Barros Eleotério 4 , \\ Priscila Soares Ferreira ${ }^{5}$, Tatiana Schmitz Duarte ${ }^{6}$
}

\begin{abstract}
The tear film plays an important role in maintaining the integrity of the ocular suface. During general anesthesia, tear production is considerably reduced, which requires care to prevent adverse effects that result in diseases of these structures. Studies comparing the effects of induction of anaesthesia with thiopental and propofol on tear production have not been carried out yet. Because these drugs are used in veterinary medicine, we decided to evaluate the tear production in 30 dogs undergoing experimental surgery as well as routine procedures at the veterinary hospital of Federal University of Viçosa. Patients were divided into two groups of equal number. All animals were sedated with clorpromazine and maintained with isoflurane in diluted oxygen. Group 1 was induced with thiopental whereas group 2 with propofol. Schirmer tear test 1 was performed before sedation (T0), 15 minutes after sedation (T1) and 10 minutes after induction of anesthesia (T2) with the drug chosen for one of the groups. There was a significant decrease in tear production for both drugs, but no significant statistical differences were found between them. Thus, considering the results and the way in which the study was conducted, we suggest protecting the cornea and conjunctiva of patients during anesthesia using any of the drugs here evaluated.
\end{abstract}

Key words: General anesthesia, surgery, dogs, veterinary ophthalmology, tear film production.

\section{RESUMO}

\section{Comparação da produção lacrimal em cães após indução anestésica com Propofol e Tiopental}

O filme lacrimal tem função importante na manutenção da integridade da superfície ocular. Durante a anestesia geral sua produção é diminuída consideravelmente, o que exige cuidados para prevenir efeitos adversos que resultam em doenças destas estruturas. Ainda não foram realizadas pesquisas comparando-se os efeitos da indução com o tiopental e com o propofol na produção lacrimal. Como estas drogas são utilizadas na Medicina Veterinária, resolveu-se avaliar a produção lacrimal de 30 cães submetidos à procedimentos cirúrgicos experimentais e de rotina no Hospital Veterinário da Universidade Federal de Viçosa. Os pacientes foram distribuídos em dois grupos de número igual. Todos os animais foram sedados com clorpromazina e mantidos com isoflurano diluído em oxigênio. O grupo 1 recebeu indução com o tiopental e o grupo 2 com propofol. Foi realizado teste lacrimal de Schirmer 1 antes da sedação (T0), 15 minutos

\footnotetext{
Recebido para publicação em novembro de 2009 e aprovado em dezembro de 2010

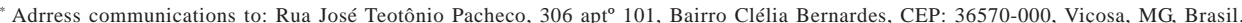

${ }^{1}$ The present study was supported by CNPQ (Brazilian Council of Research Development) and FAPEMIG (Minas Gerais Research Support Foundation)

${ }^{2}$ Médica Veterinária, Doutora. Departamento de Veterinária, Universidade Federal de Viçosa, Av. Peter Henry Rolfs, s/nº, Campus Universitário, 36570-000, Viçosa, MG, Brasil. kellycpontes@yahoo.com.br; kelly.pontes@ufv.br

${ }^{3}$ Médica Veterinária, Doutora, Departamento de Veterinária, Universidade Federal de Viçosa, Av. Peter Henry Rolfs, s/nº, Campus Universitário, 36570-000, Viçosa, MG, Brasil. andrea@ufv.br

${ }^{4}$ Médico Veterinário, Departamento de Veterinária, Universidade Federal de Viçosa, Av. Peter Henry Rolfs, s/nº, Campus Universitário, 36570-000, Viçosa, MG, Brasil. renato_ufv@hotmail.com

${ }^{5}$ Aluna de graduação em Medicina Veterinária, Departamento de Veterinária, Universidade Federal de Viçosa, Av. Peter Henry Rolfs, s/nº, Campus Universitário, 36570-000, Viçosa, MG, Brasil. psoaresferreira@hotmail.com

${ }^{6}$ Médica Veterinária, Mestre, Departamento de Veterinária, Universidade Federal de Viçosa, Av. Peter Henry Rolfs, s/nº Campus Universitário, 36570-000, Viçosa, MG, Brasil. tduarte_br@yahoo.com.br
} 
após a sedação (T1) e 10 minutos após a indução da anestesia (T2) com a droga referente ao grupo a que pertencia cada animal. Ambas as drogas levaram à diminuição considerável na produção lacrimal, sendo que não existiram diferenças significativas ao compará-las estatisticamente. Assim, diante dos resultados observados e da maneira como a pesquisa foi concebida, sugere-se a proteção da córnea e conjuntiva do paciente durante a anestesia utilizando-se qualquer uma das drogas avaliadas para a indução da anestesia.

Palavras-chave: Anestesia geral, cirurgia, cães, oftalmologia veterinária, produção de filme lacrimal.

\section{INTRODUCTION}

Optical integrity and maintenance of the cornea and normal function of the eye depend on an adequate supply of tear fluid covering the anterior segment of the ocular bulb and the structures attached to it (Samuelson, 1991). The tear film is essential for the maintenance of cornea transparency. In addition, it functions as a refractive surface, promotes nutrition and lubrication of the cornea and eyelids, removes debris and distributes leukocytes on the ocular surface (Grahn \& Storey, 2004).

Malfunction of the lacrimal system can cause adverse effects resulting in diseases in the cornea and conjunctiva (Gelatt, 1991). A defective tear film can lead to dehydration of the corneal and conjunctival epithelia, hypoxia of the corneal epithelium and subepithelial stroma, as well as secondary inflammation of the conjunctiva and cornea (Slatter, 2005).

The tear production is measured by the Schirmer tear test 1 and the Schirmer tear test 2 . The first is the most used and measures the production of basal and reflex tears. The second evaluates tear production after application of topical anesthetic and in animals with corneal injury which cannot be assessed by the Schirmer tear test 1 (Saito \& Kotani, 2001).

The Schirmer tear test 1 is performed with sterile absorbent paper strips, packed in pairs, notched at $5 \mathrm{~mm}$ from its end. Each strip is folded and placed in that slot in the lateral third of the lower eyelid fornix for one minute. The tape is rounded at the corners to minimize the irritation of the conjunctiva and is marked in millimeters. The distance from the slot to moistened side of the paper is measured immediately after removing the strip of the eye. The result is shown in millimeters per minute (Barabino et al., 2004; Slatter, 2005). In normal dogs the values for the Schirmer tear test range from 10 to $25 \mathrm{~mm}$ (with average at 21mm \pm 4.2$)$ (Gelatt, 1991).

It is known that when a patient is under general anesthesia the tear production decreases dramatically. Thus, during the anesthetic procedure, the animals must have the corneas protected by applying topical lubricants or by keeping the eyelids closed (Siffring \& Poulton, 1987; Muir, 2007).
Local anesthetics and parasympatholytic drugs (atropine, tropicamide) decrease tear production while the parasympathomimetic drugs (pilocarpine, echothiophate, isoflurophate and demecarium) increase it. Thus, for diagnostic purposes, one should avoid measuring tear production after the administration of these drugs, since they may interfere with the interpretation of examination (Slatter, 2005).

In a study comparing the effects of xylazine and butorphanol (used either in association or alone) on tear production in dogs, Dodam et al. (1998) found that xylazine did not change it, while butorphanol caused a small decrease in the production of tears. However, the combination of these two drugs resulted in marked decrease in tear production, suggesting a synergistic effect for this parameter. In another study, there was a decrease in tear production in humans undergoing general anesthesia, but the drugs used were not specified (Drupin et al., 1977). This is the first study on the effects of induction of anaesthesia with thiopental and propofol on tear production in dogs.

Barbiturates are derivatives of barbituric acid, which is a combination of malonic acid and urea. Among the barbituric acid derivatives, only thiopental and pentobarbital are used in anesthesia and are available in Brazil. They are powerful hypnotics that produce dosedependent depression of the central nervous system (CNS). Depressive effects range from mild sedation and sleep to general anesthesia to complete bulbar depression that causes death (Fantoni et al., 2006).

Propofol, a representative of the group of alkyl phenols, is a hydrophobic fluid which is stable at room temperature. It is formulated as aqueous emulsion 1\% containing $10 \%$ soybean oil, $2.25 \%$ glycerol and $1.2 \%$ purified egg phospholipid. Analgesia does not occur with this agent and the degree of muscle relaxation is moderate. It can be administered by continuous infusion or repeated doses, and induction and recovery are fast and satisfactory (Fantoni et al., 2006).

Many anesthesiologists are not aware of the necessary care related to tear production during anesthetic procedures. Moreover, except for atropine, it is unknown 
whether there is any drug which, used alone in anesthetic protocols, could compromise in a more severe way the tear film production. Studies have not been carried out in order to compare the effects of different drugs on tear production during general anesthesia in dogs. Studies to identify which drugs compromise tear production more strongly may help anesthesiologists during routine anesthesia. Although thiopental has been replaced by other drugs, it is still used in some clinics. Therefore, we decided to compare the production of the tear film in dogs when using thiopental and propofol in anesthetic induction in these patients.

\section{MATERIAL AND METHODS}

The study was approved by the Ethics Committee of the Veterinary Department, Federal University of Viçosa, under protocol number 29/2009. The assays followed the criteria recommended by the bioethical Association for Research in Vision and Ophthalmology (ARVO) National Institutes of Health Publications No 85-23: Revised 1985, according to the Nuremberg code (Goldim, 1995).

The animals were evaluated during routine and experimental surgical procedures of Veterinary Hospital, Federal University of Viçosa. A total of 30 animals of both sexes, weighing between 10 to $22 \mathrm{~kg}$, were randomly divided into two groups of 15 animals each. Group 1 (G1) received as anesthetic protocol sedation clorpromazine ${ }^{7}$ at a dose of $1 \mathrm{mg} / \mathrm{kg}$ intravenously, induction with thiopental $^{8}$ at a dose of $12.5 \mathrm{mg} / \mathrm{kg}$ intravenously and maintained with isoflurane ${ }^{9}$ diluted in $100 \%$ oxygen. In group 2 (G2), the anesthetic protocol consisted of sedation with clorpromazine ${ }^{7}$ (1 mg/kg intravenously), induction with propofol ${ }^{10}$ at a dose of $6 \mathrm{mg} / \mathrm{kg}$ intravenously and maintained with isoflurane ${ }^{9}$ diluited in $100 \%$ oxygen.

Ophthalmic evaluation was performed in all animals immediately before surgery and anesthesia, including the Robert Jones test. Only animals considered to be standards within the normal range were part of the study. The Schirmer tear test 1 was carried out in both eyes of each animal using sterile Schirmer strips ${ }^{11}$. The strip was removed from the envelope and folded into the slot at its end. After this procedure, it was inserted at the side of the lower conjunctival fornix of the right eye of the patient and hold there for 1 minute (Figure 1). During this time the eyelids of the examined eye remained manually closed. Then the same procedure was performed in the left eye using a new strip from the same manufacturer.

\footnotetext{
Longactil ${ }^{\circledR}$ - Cristália, Itapira, SP, Brazil.

${ }^{8}$ Tiopentax ${ }^{\circledR}$ - Cristália, Itapira, SP, Brazil.

${ }^{9}$ Isoforine ${ }^{\circledR}$ - Cristália, Itapira, SP, Brazil.

${ }^{10}$ Propovan ${ }^{\circledR}$ - Cristália, Itapira, SP, Brazil.

${ }^{11}$ Teste de Shirmer ${ }^{\circledR}$ - Ophthalmos, São Paulo, SP, Brazil.
}

The times for testing tear production were established as follows: immediately before sedation (T0), 15 minutes after sedative application (T1) and 10 minutes after drug inducing (T2). No lubricant or saline solution were applied to the eyes to avoid interference in the performed lacrimal tests. The procedures were performed in the same environment at constant temperature of $24^{\circ} \mathrm{C}$. The animals were kept on station in $\mathrm{T} 0$ and $\mathrm{T} 1$, and in left lateral recumbency in $\mathrm{T} 2$.

The variables were subjected to tests of normality (Lilliefors) and Homoscedasticity (Cochran). Given the normality and homoscedasticity assumptions, the data were subjected to analysis of variance (ANOVA) followed by Tukey test at a 5\% probability level. All tests were performed using the BioStat software version 5.0.

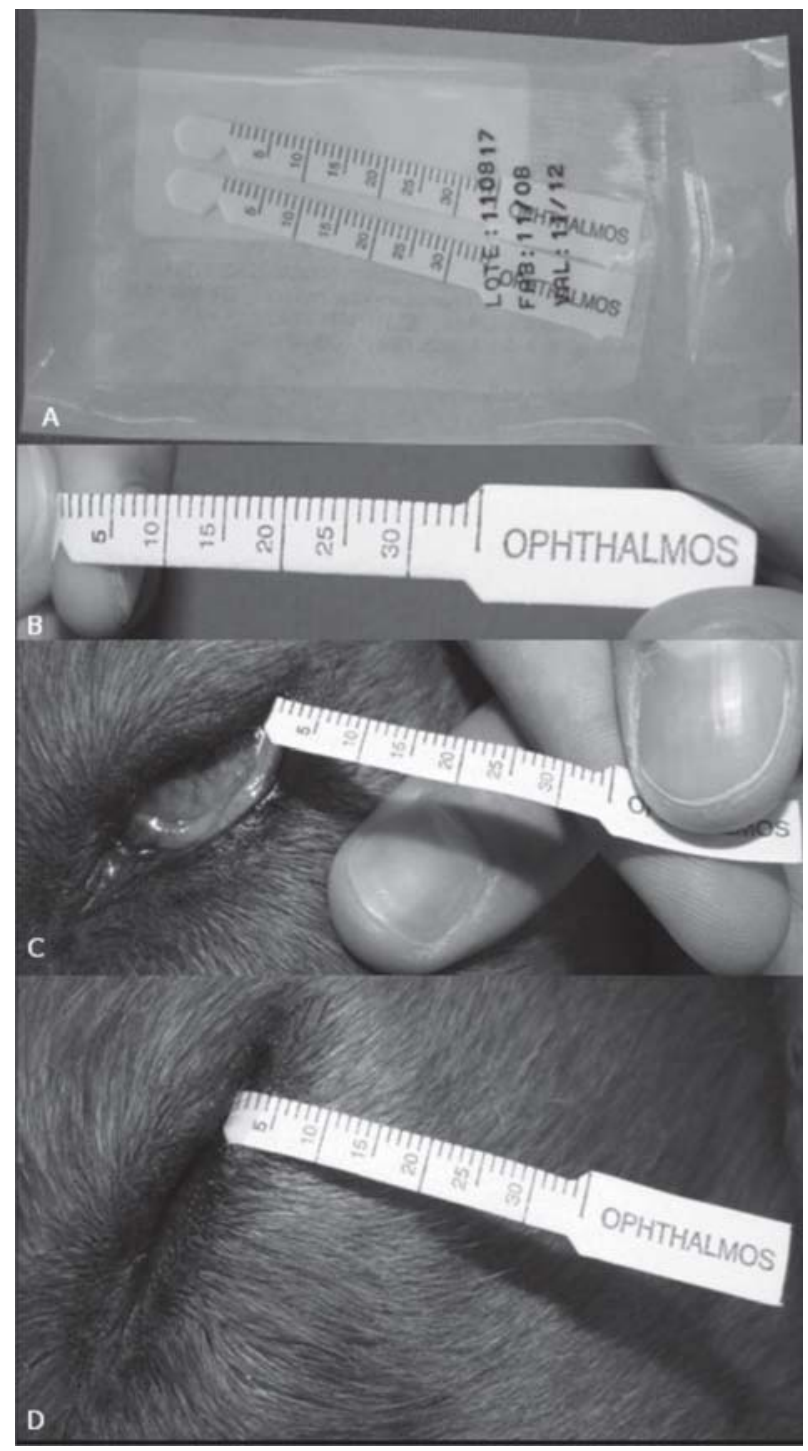

Figure 1. Schirmer tear test 1 performed in a dog under general anesthesia. A - Sterile strips for Schirmer tear test inside package; B - Same show in A folded in slot at its end; C - Placement of the strip in the lateral third of the lower conjunctival fornix of the patient; D - Test strip held in place for 1 minute. 


\section{RESULTS AND DISCUSSION}

Animals of G1 and G2 showed differences $(\mathrm{p}<0.05)$ for the Schirmer tear test 1 by the Tukey's test for the right eyes for the times T0, T1 and T2, and for the left eyes, between $\mathrm{T} 0$ and $\mathrm{T} 2$ and between $\mathrm{T} 1$ and T2 (Table 1 and 2).

In this study, the right eyes of the patients showed higher dryness than the left ones at T2. Because, at this time, the patients were evaluated in the left lateral recumbency, we assume that gravity is related to this finding, since the upper eyelid of the left eye remained more closed than the one of the right eye, which helped maintain it moistened. In contrast, the right eye was more susceptible to dryness because the eyelids remained open exposing the tear film to dehydration.

Some animals, after sedation, remained in the left lateral recumbency spontaneously. However, immediately before the test at $\mathrm{T} 1$ the animal was placed on station in order to standardize the procedure. We believe that during the time they were in the left lateral recumbency, the right eye, although to a lesser extent, has been more susceptible to drying for the same reasons mentioned above. Data analysis showed significant difference $(p<0.05)$ by the Tukey test between $\mathrm{T} 0$ and $\mathrm{T} 1$ for the right eye in both groups.

The decrease in tear production showed significant difference ( $\mathrm{p}<0.01$ ) between T0 and T2 for both eyes in both groups. This finding corroborates with those described in the literature, confirming that after general anesthesia, tear production decreases considerably (Siffring \& Poulton, 1987; Muir, 2007).

Comparing the action of thiopental and propofol as inducing drugs, this study showed that there were no significant differences ( $\mathrm{p}>0.05$ ) between groups by the Tukey test in tear production (Table 3 ). Both drugs caused a decrease in tear production, measured 10 minutes after the induction time.

Table 1. Means and standard deviations ( $\mathrm{mm} / \mathrm{min}$ ) for tear production in dogs of G1 at different observation times

\begin{tabular}{lccc}
\hline & T0 & T1 & T2 \\
\hline Right Eye & $19.8 \pm 5.4 \mathrm{a}$ & $14.6 \pm 5.0 \mathrm{~b}$ & $3.4 \pm 3.6 \mathrm{c}$ \\
Left Eye & $17.8 \pm 5.6 \mathrm{a}$ & $13.6 \pm 5.1 \mathrm{a}$ & $5.4 \pm 3.6 \mathrm{~b}$
\end{tabular}

Different letters in the same row differ at $5 \%$ probability by the Tukey test.

Table 2. Means and standard deviations ( $\mathrm{mm} / \mathrm{min}$ ) for tear production in dogs of $\mathrm{G} 2$ at different observation times

\begin{tabular}{lccc}
\hline & T0 & T1 & T2 \\
\hline Right Eye & $15.8 \pm 4.1 \mathrm{a}$ & $11.6 \pm 5.6 \mathrm{~b}$ & $2.4 \pm 3.1 \mathrm{c}$ \\
Left Eye & $14.6 \pm 3.5 \mathrm{a}$ & $12.9 \pm 4.6 \mathrm{a}$ & $3.8 \pm 5.1 \mathrm{~b}$ \\
\hline
\end{tabular}

Different letters in the same row differ at $5 \%$ probability by the Tukey test.
Table 3. Means and standard deviations ( $\mathrm{mm} / \mathrm{min}$ ) for tear production in dogs comparing the G1 and G2 at different observation times

\begin{tabular}{cccc}
\hline \multicolumn{5}{c}{ OD } \\
\hline T0 & T1 & T2 \\
\hline G1 & $19,8 \pm 5,4$ a & $14,6 \pm 5,0$ a & $3,4 \pm 3,6$ a \\
G2 & $15,8 \pm 4,1$ b & $11,6 \pm 5,6$ a & $2,4 \pm 3,1$ a \\
\hline \multicolumn{4}{c}{ OE } \\
\hline G1 & T0 & T1 & T2 \\
G2 & $17,8 \pm 5,6$ a & $13,6 \pm 5,1$ a & $5,4 \pm 3,6$ a \\
\hline
\end{tabular}

Different letters in the same column differ at $5 \%$ probability by Tukey test.

\section{CONCLUSIONS}

Considering the results and the way in which the study was conducted, it can be concluded that both thiopental and propofol similarly decrease tear production bilaterally. Thus, we emphasize the need to lubricate the cornea and conjunctiva of patients under these anesthetics seeking to avoid damage to these structures.

\section{ACKNOWLEDGMENTS}

We thank the Ophthalmos Pharmaceutical Industry Ltda. for the support given to this work.

\section{REFERENCES}

Barabino S, Chen W \& Dana, MR (2004) Tear film and ocular surface tests in animal models of dry eye: uses and limitations. Exerimental Eye Research, 79:613-621.

Dodam JR, Branson KR \& Martin DD (1998) Effects of intramuscular sedative and opioid combinations on tear production in dogs. Veterinary Ophthalmology, 1:57-59.

Drupin T, Cross DA \& Becker B (1977) Decreased basal tear production associated with general anesthesia. Archives of Ophthalmology, 95:107-108.

Fantoni DT, Cortopassi SRG \& Bernardi MM (2006) Anestésicos intravenosos e outros parenterais. In: Spinosa HS, Górniak SL \& Bernardi MM (Eds) Farmacologia Aplicada à Medicina Veterinária. 4 ed. Rio de Janeiro, Guanabara Koogan. p.132-143.

Gelatt KN (Ed) (1991) Ophthalmic examination and diagnostic procedures. Veterinary Ophthalmology. 2.ed. Philadelphia, Lea \& Febiger. p.195-235.

Goldim JR (Ed) (1995) Pesquisa em saúde e direitos dos animais. Porto Alegre, HCPA. 28p.

Grahn BH \& Storey ES (2004) Lacrimostimulants and lacrimomimetics. Veterinary Clinics of North America: Small Animal Practice, 34:739-753.

Muir WW (2007) Considerations for general anesthesia. In: Tranquilli WJ, Thurmon JC \& Grimm KA (Eds) Lumb \& Jone’s Veterinary Anesthesia and Analgesia. 4.ed. Iowa, Blackwell Publishing. p.7-30.

Saito A \& Kotani T (2001) Estimation of lacrimal level and testing methods on normal beagles. Veterinary Ophthalmology, 4:711. 
Samuelson DA (1991) Ophthalmic embryology and anatomy. In: Gelatt KN (Ed) Veterinary Ophthalmology. 2.ed. Philadelphia, Lea \& Febiger. p.3-123.

Siffring PA \& Poulton TJ (1987) Prevention of ophthalmic complications during general anesthesia. Anesthesiology, 66:569-570.

Slatter D (Ed) (2005) Sistema lacrimal. Fundamentos de Oftalmologia veterinária. 3.ed. São Paulo, Roca. p.259-281. 